\title{
ReSEARCh Article \\ Sustainable farming systems for hill areas of north coastal Andhra Pradesh
}

\author{
K. Tejeswara Rao, A. Upendra Rao, D. Sekhar and P. Uday Babu
}

\begin{abstract}
SUMMARY
An on-station farming system experiment was carried for two years during 2012-13 and 2013-14, at Agricultural Research Station, Seethampeta, Andhra Prtadesh, India to arrive a profitable farming system module for hilly and agency area of north coastal districts in Andhra Pradesh, where major population is scheduled tribes. Rice-Maize system,Paddy - Dairy - cum poultry system, Paddy- Fish - Banana-Vegetable system and Paddy-Dairy cum apiary system were the test modules, where rice- maize is the traditional system considered as check. Among different integrated farming system modules evaluated for two years for hilly areas of north coastal Andhra Pradesh showed that, Paddy -Dairy - poultry system recorded 202 per cent higher rice equivalent yield, 97 per cent higher gross returns, 191 per cent higher net returns and 134 per cent additional man days over sole crop component, while B:C ratio was higher with Paddy-Dairy cum apiary system.
\end{abstract}

Key Words : Integrated farming systems, Rice equivalent yield, Economics, Employment generation

How to cite this article : Tejeswara Rao, K., Upendra Rao, A., Sekhar, D. and Uday Babu, P. (2021). Sustainable farming systems for hill areas of North coastal Andhra Pradesh. Internat. J. Plant Sci., 16 (1): 83-86, DOI: 10.15740/HAS/IJPS/16.1/83-86, Copyright@, 2021: Hind Agri-Horticultural Society.

Article chronicle : Received : 17.08.2020; Revised : 19.11.2020; Accepted : 21.12.2020

MEMBERS OF THE RESEARCH FORUM

Author to be contacted :

K. Tejeswara Rao, Agricultural Research Station (ANGRAU), Seethampeta (A.P.) India

Email : tejaseniorscientist@gmail.com

Address of the Co-authors:

A. Upendra Rao and P. Uday Babu, Agricultural Research Station (ANGRAU), Seethampeta (A.P.) India

$-\overline{\text { D. Sekhar, Department of Agronomy, Regional Agricultural Research }}$

Station, Chintapalle, Visakhapatnam (A.P.)

(Email: sekhardesagiri@gmail.com 